p-ISSN: 1979-0643

e-ISSN: 2685-7324

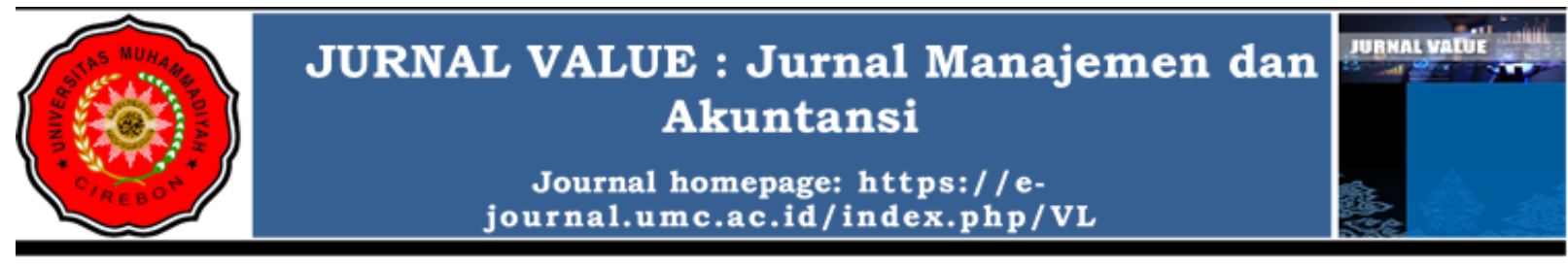

\title{
ANTESEDEN PENINGKATAN PENGGUNAAN ONLINE FOOD DELIVERY PADA MASA PANDEMI COVID-19
}

\author{
Novita ${ }^{1}$ \\ Ari Wijaya ${ }^{2}$ \\ ${ }^{1}$ Fakultas Ilmu Sosial dan Humaniora, Universitas Bunda Mulia \\ Email : novita@bundamulia.ac.id \\ ${ }^{2}$ Fakultas Ilmu Sosial dan Humaniora, Universitas Bunda Mulia \\ Email : awijaya@gmail.com
}

Diterima : 28 Agustus 2021

Direvisi : 19 September 2021

Dipublikasikan : 24 November 2021

\begin{abstract}
Abstrak
Pandemi Covid-19 mengakibatkan perubahan pola kehidupan masyarakat, termasuk dalam hal kebutuhan akan teknologi. Sejak terjadinya pandemi Covid-19, semakin banyak teknologi baru yang muncul dan dimanfaatkan oleh masyarakat untuk menunjang kebutuhan sehari-hari. Saat ini hampir semua kegiatan masyarakat dilakukan menggunakan teknologi, mulai dari absen kantor yang dilakukan secara digital, rapat melalui virtual, pemesanan makanan melalui online, bahkan ibadah pun juga harus melalui jaringan digital. Online food delivery merupakan jasa antar makanan yang dilakukan oleh situs layanan antar online, baik melalui aplikasi jasa antar seperti GoFood atau GrabFood maupun aplikasi lainnya. Di tengah pandemi Covid-19 seperti sekarang ini, penggunaan online food delivery sangat disukai oleh masyarakat Indonesia. Pemberlakuan Pembatasan Kegiatan Masyarakat (PPKM) membatasi aktivitas konsumen untuk menikmati makanan yang diinginkan di suatu restoran. Jadi pemesanan makanan melalui online food delivery dianggap merupakan solusi terbaik. Penelitian ini menggunakan metode penelitian kuantitatif. Pengumpulan data dalam penelitian ini dengan melakukan penyebaran kuesioner secara online pada 270 responden. Aplikasi pengolahan data yang digunakan adalah SmartPLS 3.0. Penelitian ini menunjukkan bahwa e-satisfaction dipengaruhi oleh perceived usefulness, perceived ease of use, dan dinning attitude. Keywords: online food delivery, dinning attitude, e-satisfaction
\end{abstract}

\section{PENDAHULUAN}

Indonesia telah mengalami keadaan pandemi Covid-19 selama lebih dari satu tahun. Selama lebih dari satu tahun tersebut masyarakat Indonesia yang terpapar Covid-19 telah mencapai 3,4 juta orang, dimana lebih dari 94.000 diantaranya meninggal. Pandemi telah menciptakan perubahan di semua aspek kehidupan, sehingga seluruh masyarakat harus beradaptasi dan mulai hidup berdampingan dengan Covid19. Pembatasan sosial mulai dilakukan untuk mengendalikan penyebaran Covid-19. Salah satunya kebijakan Pembatasan Sosial Berskala Besar (PSBB) yang diatur dalam Peraturan Pemerintah No. 21/2020 tentang Pembatasan Sosial Berskala Besar dalam Rangka Percepatan Penanganan Covid-19. Peraturan tersebut juga didukung oleh Peraturan Menteri Kesehatan No. 9/2020 tentang Pedoman PSBB. Hal ini kemudian diikuti dengan kebijakan PPKM yaitu Pemberlakukan Pembatasan Kegiatan Masyarakat (Permatasari, 2021).

Kegiatan pembatasan tersebut dilakukan dengan cara membatasi aktivitas sosial masyarakat. Hal ini disebabkan karena virus Covid-19 tergolong mudah menular, khususnya melalui interaksi yang dekat antar orang ke orang. Selain di Jakarta, pelaksanaan pembatasan interaksi sosial dilakukan hampir di semua 
kota besar di Indonesia. Padahal Indonesia merupakan negara yang memiliki masyarakat dengan karakteristik suka mengonsumsi makanan sekaligus bersosialisasi (Novita \& Rowena, 2019). Dengan adanya peraturan PPKM, masyarakat dianjurkan untuk tidak berpergian kecuali jika sangat diperlukan. Hal ini terutama berlaku di tempat-tempat umum yang berpotensi menimbulkan keramaian seperti pusat perbelanjaan, transportasi publik, tempat peribadatan, dan fasilitas kesehatan. Situasi ini berdampak besar pada kehidupan masyarakat, terutama perekonomian. Salah satu sektor bisnis yang juga terdampak adalah sektor bisnis restoran. Pandemi Covid-19 telah mengubah kebiasaan masyarakat yang lebih banyak memanfaatkan waktu luang untuk tidak pergi ke tempat ramai seperti restoran. Kapasitas restoran juga tidak diperbolehkan penuh juga telah menurunkan omzet pengusaha restoran. Tetapi hal baiknya adalah adanya terjadinya peningkatan transaksi di layanan pesan antar. Peningkatan ini selaras dengan implementasi swakarantina dan work from home (WFH) untuk mencegah penyebaran virus Covid-19 (Jayani, 2021)

Online food delivery merupakan jasa antar makanan yang dilakukan oleh situs layanan antar online, baik melalui aplikasi jasa antar seperti GoFood atau GrabFood maupun aplikasi milik restoran itu sendiri (Kaur et al., 2020). Di tengah pandemi Covid-19 seperti sekarang ini, penggunaan online food delivery sangat disukai oleh masyarakat Indonesia. Kebijakan PPKM membatasi aktivitas konsumen untuk menikmati makanan yang diinginkan di suatu restoran. Jadi pemesanan makanan melalui online food delivery dianggap merupakan solusi terbaik (Saad, 2021) Riset Nielsen Singapura menunjukkan bahwa sekitar 58\% masyarakat Indonesia membeli makanan melalui aplikasi secara online melalui smartphone. Rata-rata masyarakat membeli makanan melalui aplikasi pesan-antar makanan dari smartphone secara online sebanyak 2,6 kali per minggu. Transaksi ini mengalami peningkatan sebesar $20 \%$ dibandingkan sebelum terjadinya pandemi Covid-19 (Jayani, 2021).

Fitur layanan ini tidak hanya tersedia melalui aplikasi Gojek dan Grab saja, tetapi juga mulai diikuti oleh perusahaan digital lain. Beberapa perusahaan teknologi digital seperti Google, Instagram, Shopee, Tokopedia, hingga DANA mulai menyediakan layanan serupa. Tren online food delivery terjadi sebagai dampak perubahan perilaku masyarakat akibat adaptasi kebiasaaan yang berbeda selama pandemi Covid19. Keinginan masyarakat untuk terus melakukan pemesanan makanan secara online dipengaruhi oleh perubahan sikap masyarakat dalam menikmati makanan yang diinginkan, hal ini dinamakan dinning attitude (Al Amin et al., 2020). Dinning attitude pada masyarakat Indonesia mulai berubah sebagai akibat dari pandemi Covid-19. Konsumen yang mulai membiasakan diri menerapkan jarak aman untuk menghindari penularan Covid-19, merasa nyaman untuk menikmati makanan restoran yang mereka inginkan melalui aplikasi online dibandingkan harus mengunjungi restoran tersebut. Ketika konsumen merasa puas pada penggunaan online food delivery, maka konsumen akan berulang kali memesan melalui aplikasi tersebut (Ngoc \& Uyen, 2015).

Berdasarkan latar belakang diatas, rumusan masalah dalam penelitian ini ditentukan sebagai berikut :

1. Apakah perceived usefulness berpengaruh terhadap dinning attitude masyarakat Indonesia pada online food delivery?

2. Apakah perceived ease of use berpengaruh terhadap dinning attitude masyarakat Indonesia pada online food delivery?

3. Apakah perceived usefulness berpengaruh terhadap e-satisfaction masyarakat Indonesia pada online food delivery?

4. Apakah perceived ease of use berpengaruh terhadap e-satisfaction masyarakat Indonesia pada online food delivery?

5. Apakah dinning attitude berpengaruh terhadap e-satisfaction masyarakat Indonesia pada online food delivery?

\section{KAJIAN PUSTAKA DAN PENGEMBANGAN HIPOTESIS Perceived Usefulness}

Perceived usefulness adalah sejauh mana seseorang percaya bahwa menggunakan teknologi tertentu dapat meningkatkan kinerja pekerjaannya (Guriting \& Oly Ndubisi, 2006). Beberapa penelitian menunjukkan bahwa perceived usefulness yang tinggi sering menghasilkan kinerja yang tinggi untuk penggunanya. Dalam kasus penggunaan aplikasi online, perceived usefulness memiliki dampak yang positif 
untuk mencapai kinerja yang lebih tinggi dari penggunaan aplikasi online. Lebih penting lagi, perceived usefulness diidentifikasi sebagai prediktor penting dalam menciptakan kepuasan konsumen dan menjadikan penggunanya lebih produktif (Teo \& Teo, 2011).

\section{Perceived Ease of Use}

Perceived ease of use mengacu pada seberapa jelas proses interaksi dengan sistem atau aplikasi. Hal ini juga dapat diartikan sebagai kemudahan dalam mendapatkan sistem untuk melakukan apa yang diperlukan. Perceived ease of use juga merupakan upaya mental yang diperlukan untuk berinteraksi dengan sistem dan kemudahan penggunaan system (Guriting \& Oly Ndubisi, 2006). Studi sebelumnya menunjukkan adanya efek positif yang berhubungan dengan hasil yang dirasakan dan kemudahan penggunaan teknologi. Perceived ease of use adalah tingkat kemudahan yang terkait dengan penggunaan teknologi dan mencerminkan keyakinan bahwa menggunakan teknologi tidak memerlukan usaha yang berlebihan (Stocchi et al., 2019).

\section{Dinning Attitude}

Sikap adalah dampak evaluatif dari perasaan positif atau negatif yang ditampilkan oleh seorang individu pada suatu objek tertentu (Novita \& Rowena, 2019). Pandangan konsumen tentang pentingnya penggunaan suatu teknologi dapat didefinisikan sebagai sikap konsumen. Sikap juga dapat didefinisikan sebagai sejauh mana seseorang secara positif telah menunjukkan perilaku tertentu mengenai objek tertentu. Ketika konsumen menunjukkan sikap positif terhadap keadaan atau objek tertentu, hal ini akan mempengaruhi persepsi mereka terhadap suatu objek tersebut (Ha \& Janda, 2012). Dinning attitude adalah perasaan evaluatif dari konsumen tentang cara mereka mengonsumsi atau memperoleh makanan hingga siap untuk dikonsumsi. Sikap positif konsumen tentang dinning attitude membuat konsumen terus mempertahankan layanan transaksi dan menumbuhkan sikap saling menguntungkan dalam mengonsumsi makanan (Al Amin et al., 2020).

\section{E-Satisfaction}

E-satisfaction adalah indeks pengukuran pasca aktivitas yang mengukur kondisi perasaan pelanggan tentang pembelian masa lalu dan pengalaman berbelanja menggunakan online (Chiu \& Cho, 2019). Kepuasan juga digambarkan sebagai ringkasan psikologis dari keadaan yang dihasilkan ketika emosi tidak terkonfirmasi untuk digabungkan dengan perasaan pelanggan sebelumnya tentang pengalaman pelanggan. Persepsi konsumen atas kepuasan ini dapat didasarkan pada kenyamanan online, merchandising (penawaran produk dan informasi produk), desain situs, dan keamanan finansial dalam penggunaan aplikasi online (Alex \& Thomas, 2011).

\section{Pengaruh Perceived Usefulness Terhadap Dinning Attitude}

Perceived Usefullness didefinisikan sebagai sejauhmana konsumen merasa bahwa penggunaan suatu sistem akan dapat meningkatkan kinerja kegiatan mereka (Bashir \& Madhavaiah, 2015). Prediktor utama pembentuk sikap pelanggan untuk mengadopsi suatu teknologi baru adalah perceived usefulness. Ketika konsumen menganggap bahwa suatu aplikasi teknologi memiliki manfaat untuk memudahkan kegiatan konsumen, maka mereka akan memiliki sikap yang positif pada aplikasi teknologi tersebut (Kang \& Namkung, 2019). Semakin banyak pelanggan yang berpersepsi positif pada penggunaan suatu aplikasi, maka penyedia layanan akan lebih menyempurnakan fitur-fitur yang bermanfaat seperti petunjuk peta, telepon langsung, notifikasi, dan lain-lain sehingga sikap konsumen akan semakin positif pada aplikasi tersebut (Makanyeza, 2017). Dalam konteks online delivery order, perceived usefulness merupakan penyebab terbentuknya sikap pelanggan dan berdampak pada niat berperilaku bagi konsumen (Saad, 2021). Berdasarkan teori diatas, peneliti menentukan hipotesis 1 sebagai berikut :

H1 : Perceived usefulness berpengaruh secara positif dan signifikan terhadap dining attitude.

\section{Pengaruh Perceived Ease of Use Terhadap Dinning Attitude}

Beberapa penelitian sebelumnya menemukan bahwa perceived ease of use merupakan faktor utama penentu penerimaan penggunaan suatu sistem teknologi (Guriting \& Oly Ndubisi, 2006). Teknologi seharusnya mudah untuk digunakan untuk sebagai dasar untuk meningkatkan penerimaan konsumen atas teknologi tersebut 
(Bashir \& Madhavaiah, 2015). Teknologi baru yang dianggap mudah untuk digunakan biasanya akan disukai oleh konsumen (Wang et al., 2003). Hal ini didukung oleh penelitian yang dilakukan oleh (Kang \& Namkung, 2019) yang menemukan bahwa kemudahan penggunaan e-shopping berpengaruh terhadap sikap konsumen dalam berbelanja online. Berdasarkan teori diatas, peneliti menentukan hipotesis 2 sebagai berikut :

$\mathrm{H} 2$ : Perceived ease of use berpengaruh secara positif dan signifikan terhadap dining attitude

\section{Pengaruh Perceived Usefulness Terhadap E-satisfaction}

Faktor pendorong utama agar konsumen menggunakan digital platform adalah kepuasan (Kotler et al., 2019). Kepuasan konsumen untuk menggunakan aplikasi untuk melakukan transaksi pembelian dipengaruhi oleh manfaat yang dirasakan oleh konsumen ketika menggunakan aplikasi tersebut (Saad, 2021). Manfaat yang menguntungkan dari sebuah penggunaan aplikasi dan pengalaman pembelian online sebelumnya akan mempengaruhi kepuasan konsumen, selanjutnya akan berdampak pada sikap konsumen dan niat perilaku konsumen terhadap layanan pengiriman makanan online (Ngoc \& Uyen, 2015).

H3 : Perceived usefulness berpengaruh secara positif dan signifikan terhadap e-satisfaction

\section{Pengaruh Perceived ease of use Terhadap E-satisfaction}

Konsumen akan melakukan penilaian setelah menggunakan aplikasi pada transaksi pembelian. Ketika konsumen merasa aplikasi tersebut mudah untuk digunakan, maka mereka akan lebih puas dan terus menggunakan aplikasi tersebut (Makanyeza, 2017). Sebagian besar persepsi pelanggan dibentuk oleh pengalaman masa lalu dan hal tersebut menentukan kepuasan dan perilaku mereka dalam menggunakan aplikasi secara terus menerus (Bashir \& Madhavaiah, 2015). Pada masa pandemi Covid-19 dimana terdapat pembatasan jarak dan berbagai pembatasan sosial membuat konsumen bergantung pada aplikasi untuk pemenuhan kebutuhan hidup. Kemudahan aplikasi akan menguntungkan di masa pandemi ini. Kemudahan penggunaan tersebut berpengaruh pada kepuasan konsumen dan membuat konsumen tetap menggunakan aplikasi tersebut untuk memenuhi kebutuhan hidupnya.

H4 : Perceived ease of use berpengaruh secara positif dan signifikan terhadap e-satisfaction

\section{Pengaruh Dining Attitude terhadap E-Satisfaction}

E-satisfaction merupakan kepuasan pelanggan tentang pembelian sebelumnya pada perusahaan penyedia aplikasi yang digunakan (Baabdullah et al., 2019). E-satisfaction dianggap sebagai kepuasan pelanggan tentang pengalaman sebelumnya dengan perusahaan online tertentu (Ryu et al., 2012). Sikap pelanggan merupakan salah satu elemen untuk mengukur kepuasan. Dihubungkan dengan aplikasi online food delivery, dinning attitude digunakan untuk mengukur sikap konsumen dalam mengonsumsi makanan melalui adopsi teknologi tertentu. Ketika sikap makan pelanggan menggunakan online food delivery adalah positif, konsumen menjadi lebih puas menggunakan aplikasi tersebut. Sikap positif konsumen terhadap online food delivery mempengaruhi pelanggan untuk lebih puas dengan layanan yang disediakan oleh aplikasi online. Berdasarkan teori diatas, peneliti menentukan hipotesis 3 sebagai berikut :

H5 : Dinning attitude berpengaruh secara positif dan signifikan terhadap e-satisfaction.

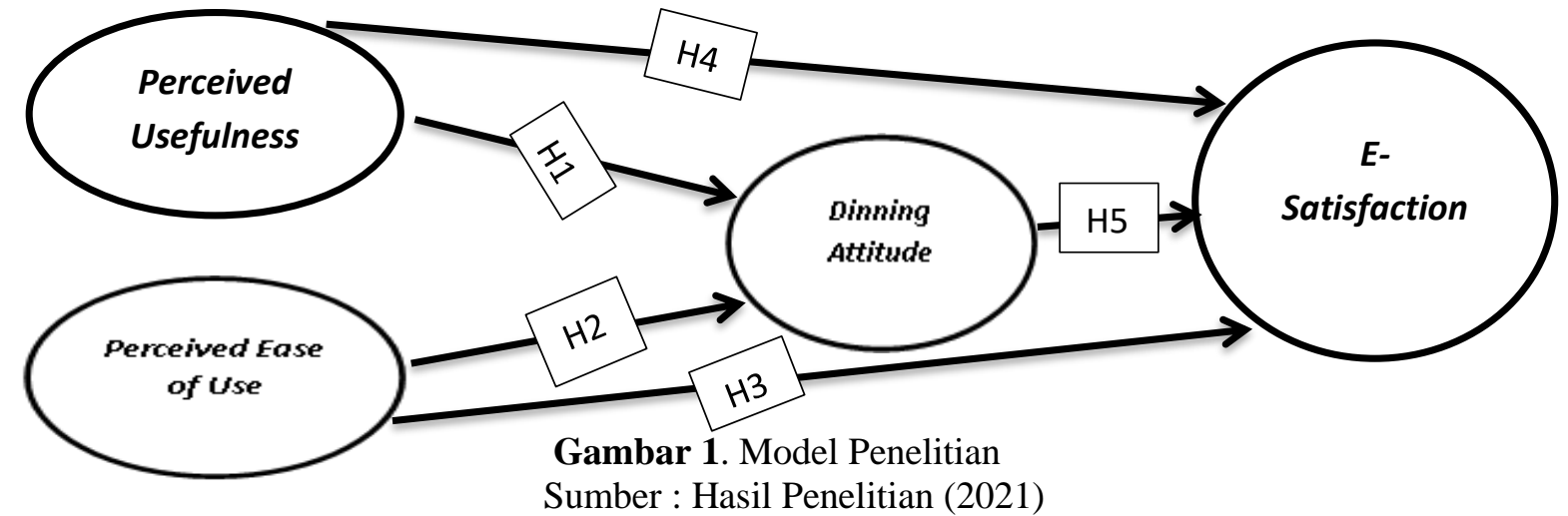




\section{METODE PENELITIAN \\ Prosedur Penelitian}

Jenis penelitian yang digunakan dalam penelitian ini menggunakan metode penelitian kuantitatif. Metode kuantitatif sudah cukup lama digunakan sebagai metode dalam sebuah penelitian. Dalam metode kuantitatif data penelitian berupa angka-angka dan kemudian diolah menjadi analisis statistik. Dalam penelitian kuantitatif, beberapa hal yang telah terjadi lebih dahulu dapat dijadikan sebagai teori dalam prediksi ilmiah atau untuk menjelaskan suatu penelitian yang mengembangkan konsep teori yang berbeda dan membatasi pemikiran (Sugiyono, 2017).

Metode pengumpulan data yang digunakan dalam penelitian ini adalah dengan cara menyebarkan kuesioner secara online. Kuesioner atau angket adalah teknik pengumpulan data yang dilakukan dengan memberi pernyataan tertulis kepada responden untuk dijawab sesuai tingkatan yang dirasakan responden mulai dari sangat tidak setuju hingga sangat setuju. Penggunaan kuesioner dilakukan bila jumlah responden cukup besar dan tersebar di berbagai wilayah. Kuesioner menggunakan bahasa Indonesia, menggunakan google docs dan disebarkan kepada responden secara langsung ataupun melalui internet. Skala pengukuran dalam kuesioner penelitian ini menggunakan skala likert. Skala likert digunakan untuk mengukur sikap, pendapat atau persepsi seseorang mengenai sebuah fenomena sosial atau disebut juga variabel penelitian. Jawaban dalam skala likert memiliki gradasi atau tingkatan mulai dari sangat negatif sampai sangat positif yang dapat diubah dengan kata-kata lain seperti sangat tidak setuju hingga sangat setuju. Dalam mengisi kuesioner, responden diminta untuk menanggapi pernyataan dalam bentuk skala likert, responden menentukan tingkat persetujuan mereka terhadap suatu pernyataan dengan memilih salah satu dari pilihan yang tersedia.

Populasi adalah wilayah generalisasi (sasaran) yang meliputi subjek atau objek yang memiliki kualitas dan karakteristik yang sesuai dengan ketetapan seorang peneliti. Penentuan populasi untuk mempelajari karakteristik atau sifat dari subjek atau objek penelitian dengan tujuan menarik kesimpulan dari penelitian tersebut (Siregar, 2017). Populasi dalam penelitian ini adalah masyarakat Indonesia yang pernah melakukan pembelian makanan di restoran melalui online food delivery selama masa pandemi Covid-19 (dimulai dari Maret 2020 sampai sekarang). Jumlah sampel ditentukan sebesar 270 responden berdasarkan data yang terkumpul sampai dengan waktu yang telah ditentukan menggunakan purposive sampling.

\section{Pengembangan Instrumen}

Variabel dalam penelitian ini dibagi menjadi dua, yaitu :

1. Variabel bebas, yaitu variabel yang mempengaruhi atau yang menjadi sebab perubahannya atau timbulnya variabel terikat. Variabel bebas dalam penelitian ini adalah perceived usefulness, perceived ease of use dan dinning attitude. Perceived Usefullness didefinisikan sebagai sejauhmana konsumen merasa bahwa penggunaan suatu sistem akan dapat meningkatkan kinerja kegiatan mereka (Bashir \& Madhavaiah, 2015). Perceived ease of use adalah sejauhmana konsumen menganggap bahwa suatu aplikasi teknologi memiliki manfaat untuk memudahkan kegiatan mereka (Kang \& Namkung, 2019). Dinning attitude adalah sikap masyarakat dalam menikmati makanan yang diinginkan (Al Amin et al., 2020).

2. Variabel terikat, yaitu variabel yang di pengaruhi atau yang menjadi akibat karena adanya variabel bebas. Variabel terikat dalam penelitian ini adalah e-satisfaction. E-satisfaction merupakan kepuasan pelanggan tentang pembelian sebelumnya pada perusahaan penyedia aplikasi yang digunakan (Baabdullah et al., 2019).

Dalam penelitian ini, peneliti menggunakan jenis instrumen angket atau kuesioner dengan pemberian skor sebagai berikut:

1. SS : Sangat setuju Diberi skor 5

2. $\mathrm{S}$ : Setuju Diberi skor 4

3. N : Netral Diberi skor 3

4. TS : Tidak setuju Diberi skor 2

5. ST : Sangat tidak setuju Diberi skor 1 


\section{Teknik Analisis Data Uji Kesahihan}

Kesahihan adalah menunjukkan sejauh mana suatu alat ukur mampu mengukur apa yang ingin diukur. Pengujian validitas dalam penelitian ini menggunakan uji convergent validity dan discriminant validity. Kesahihan konvergen digunakan berhubungan dengan prinsip bahwa pengukur-pengukur dari suatu konstruk seharusnya berkorelasi tinggi. Kesahihan konvergen dilihat dari hasil loading faktor untuk setiap indikator konstruk dengan nilai loading factor $>0,7$, Selain dari loading factor, pengukuran kesahihan konvergen diukur dengan nilai Average Variance Extracted (AVE) harus > 0,5 yang mempunyai arti bahwa 50\% atau lebih varian dari indikator dapat dijelaskan. Selanjutnya, discriminant variabel berhubungan dengan prinsip pengukur konstruk yang berbeda seharusnya tidak berkorelasi tinggi. Cara untuk menguji kesahihan diskriminan dengan indikator refleksi yaitu dengan melihat cross loading setiap variabel harus > 0,7 (Ghozali, 2015).

\section{Uji Keandalan}

Keandalan adalah untuk mengetahui sejauh mana hasil pengukuran tetap konsisten, apabila dilakukan pengukuran dua kali atau lebih terhadap gejala yang sama dengan menggunakan alat pengukur yang sama pula. Pengujian terhadap tingkat keandalan dimaksudkan untuk mengetahui apakah kuesioner dapat memberikan ukuran yang konstan atau tidak. Untuk mengukur keandalan, dapat dilakukan dengan uji Cronbach Alpha dan Composite Reliability. Nilai Cronbach Alpha dan Composite Reliability harus berada di atas 0,70 untuk menunjukkan konsistensi reliabilitas yang memuaskan (Ghozali, 2015).

\section{Analisis Koefisien Korelasi}

Analisis korelasi adalah suatu teknik statistik yang digunakan untuk mengukur keeratan hubungan atau korelasi antara dua peubah. Koefisien korelasi mempunyai nilai antara -1 sampai 1 . Nilai $r=-1$ yang disebut dengan linier sempurna negatif, terjadi apabila contoh atau kombinasi terletak tepat pada suatu garis lurus yang mempunyai kemiringan negatif. Nilai $r=1$ disebut dengan linier sempurna positif, dan hal ini terjadi apabila semua titik contoh terletak tepat pada satu garis lurus dengan kemiringan positif. Nilai koefisien korelasi yang mendekati -1 atau 1 menyatakan bahwa hubungan kedua peubah adalah kuat atau korelasi kedua peubah tinggi. Akan tetapi apabila nilai $r$ mendekati 0 , hubungan antara kedua peubah sangat lemah atau mungkin tidak ada sama sekali.

\section{R Square}

Nilai R Square adalah koefisien determinasi pada konstruk endogen. R Square digunakan untuk mengetahui seberapa besar pengaruh antar variable.

\section{Partial Least Squares (PLS)}

Partial least square atau disingkat PLS merupakan jenis SEM yang berbasisi komponen dengan sifat konstruk formatif. PLS pertama kali dikembangkan oleh HermanWold akhir 1960an untuk mengolah data di bidang econometrics sebagai alternative SEM dengan dasar teori yang lemah, dan berfungsi hanya sebagai alat analisis predictor bukan uji model. PLS juga dapat disebut sebagai teknik prediction-oriented. Pendekatan PLS secara khusus berguna juga untuk memprediksi peubah gayut dengan melibatkan sejumlah besar peubah gayut. PLS dapat juga digunakan dalam memprediksi dalam model sehingga PLS sering diaplikasikan tidak semata dalam analisis konfirmatori tetapi juga dalam studi eksploratori ketika dasar teorinya masih lemah. Pendekatan PLS adalah distribution free (tidak mengasumsikan data berdistribusi tertentu, dapat berupa nominal, kategori, ordinal, interval dan rasio). PLS awalnya diberi nama NIPALS (Nonlinear Iterative Partial Least Square), dengan pendekatan PLS diasumsikan bahwa semua ukuran variance adalah variance yang berguna untuk dijelaskan. Oleh karena pendekatan untuk mengestimasi peubah laten dianggap sebagai kombinasi linear dari indikator, maka mampu menghindarikan masalah indereminacy dan memberikan definisi yang pasti dari komponen skor. Dalam PLS arah hubungan kausalitas dari indikator ke konstruk atau membentuk konstruk. Sesama indikator diasumsikan tidak berkorelasi sehingga tidak perlu diuji konsistensi / reliabilitas internal. Hilangnya salah satu indikator dapat mengakibatkan perubahan makna dari konstruk (Ghozali, 2015). 


\section{Spesifikasi Model dengan PLS}

Model hubungan semua variabel laten dalam PLS terdiri dari tiga ukuran yaitu: (1) inner model yang menspesifikasi hubungan anta variabel laten (structural model) yang menggambarkan hubungan antara variabel laten berdasarkan pada substantive theory (2) outer model yang menspesifikasi hubungan antara variabel laten dengan indikator. Outer model sering juga disebut outer relation yang mendefinisikan bagaimana setiap blok indikator berhubungan dengan variabel latennya dan (3) estimasi nilai dari variabel laten (weight relation). Model hubungan dapat diasumsikan bahwa variabel laten dan indicator atau manifest variabel di skala zero means dan unit variance (nilai standardized) sehingga parameter lokasi (parameter konstanta) dapat dihilangkan dalm model tanpa memengaruhi nilai generalisasi (Chin et al dalam Mustafa dan Wijaya, 2012).

\section{HASIL DAN PEMBAHASAN \\ Deskripsi Responden}

Peneliti berhasil mengumpulkan 270 responden sampai pada batas waktu yang telah ditentukan. Responden yang tidak memenuhi syarat sebagai responden, tidak dapat mengisi kuisioner lebih lanjut.

\section{Tabel 1. Profil Responden}

\begin{tabular}{rlll}
\hline & Karakteristik Responden & Jumlah & Persentase \\
\hline \multirow{2}{*}{ Gender } & Laki-Laki & 115 & $43 \%$ \\
\cline { 2 - 4 } & Perempuan & 155 & $57 \%$ \\
\hline \multirow{3}{*}{ Usia } & $<20$ Tahun & 12 & $4 \%$ \\
\cline { 2 - 4 } & 21-30 Tahun & 110 & $41 \%$ \\
\cline { 2 - 4 } & 31-40 Tahun & 102 & $38 \%$ \\
\cline { 2 - 4 } & $>$ 40 Tahun & 46 & $17 \%$ \\
\hline \multirow{3}{*}{ Pekerjaan } & Pelajar/Mahasiswa & 12 & $5 \%$ \\
\cline { 2 - 4 } & Karyawan Swasta & 103 & $38 \%$ \\
\cline { 2 - 4 } & PNS & 100 & $37 \%$ \\
\cline { 2 - 4 } & Wirausaha & 55 & $20 \%$ \\
\hline
\end{tabular}

Sumber : data primer $(\mathrm{n}=270)$

Dapat dilihat pada tabel diatas mengenai pengolahan data profil responden, dimana mayoritas responden sebesar 57\% (155 responden) adalah perempuan. Berdasarkan data yang diperoleh, mayoritas responden berusia 21-30 tahun sebesar 41\% (110 responden) dan berusia 31-40 tahun juga tidak kalah tinggi yaitu sebesar 38\% (102 responden). Sedangkan untuk pekerjaan dari mayoritas responden adalah karyawab swasta sebesar 38\% (103 responden) dan PNS sebesar 37\% (100 responden).

\section{Uji validitas}

Uji validitas terdiri atas validitas konvergen dan validitas diskriminan. Cara untuk menguji validitas dengan reflektif yaitu dengan melihat nilai dari tiap indikator harus lebih dari 0,7 sehingga dapat disimpulkan bahwa pengukuran tersebut memenuhi kriteria validitas konvergen (Hair et al., 2017).

Tabel 2. Outer Loading

\begin{tabular}{lllll}
\hline & $\begin{array}{l}\text { Perceived } \\
\text { Usefulness }\end{array}$ & $\begin{array}{l}\text { Perceived Ease of } \\
\text { Use }\end{array}$ & $\begin{array}{l}\text { Dinning } \\
\text { Attitude }\end{array}$ & $\begin{array}{l}\text { E- } \\
\text { Satisfaction }\end{array}$ \\
\hline PU1 & 0.842 & & & \\
\hline PU2 & 0.833 & & \\
\hline PU3 & 0.707 & & \\
\hline PE1 & & 0.806 & \\
\hline
\end{tabular}


Jurnal Value, 16 (2), Hal. 441 - 452

\begin{tabular}{|c|c|c|c|}
\hline PE2 & 0.806 & & \\
\hline PE3 & 0.830 & & \\
\hline DA1 & & 0.877 & \\
\hline DA2 & & 0.871 & \\
\hline ESAT1 & & & 0.895 \\
\hline ESAT2 & & & 0.862 \\
\hline
\end{tabular}

Sumber : Data primer $(\mathrm{n}=270$ responden

Hasil data outer loading menunjukkan bahwa semua kosntruk indikator reflektif tiap variabel menghasilkan nilai outer loading faktor melebihi 0,7 yang berarti semua indikator konstruk adalah valid dan memenuhi syarat uji discriminant validity.

Tabel 3. Average Variance Extracted (AVE)

\begin{tabular}{ll}
\hline \multicolumn{1}{c}{ Variabel } & AVE \\
\hline Perceived Usefulness & 0.634 \\
\hline Perceived Ease of Use & 0.718 \\
\hline Dinning Attitude & 0.770 \\
\hline E-Satisfaction & 0.809 \\
\hline Sumber : Data primer (n=270 responden)
\end{tabular}

Hasil Average Variance Extracted (AVE) menunjukkan bahwa semua konstruk reflektif menghasilkan AVE dengan angka melebihi 0,5 sehingga dengan demikian dapat memenuhi persyaratan validitas konvergen.

Tabel 4. Cross Loading

\begin{tabular}{lllll}
\hline & $\begin{array}{l}\text { Perceived } \\
\text { Usefulness }\end{array}$ & $\begin{array}{l}\text { Perceived Ease } \\
\text { of Use }\end{array}$ & $\begin{array}{l}\text { Dinning } \\
\text { Attitude }\end{array}$ & $\begin{array}{l}\text { E- } \\
\text { Satisfaction }\end{array}$ \\
\hline PU1 & $\mathbf{0 . 8 4 2}$ & 0.595 & 0.621 & 0.544 \\
\hline PU2 & $\mathbf{0 . 8 3 3}$ & 0.566 & 0.641 & 0.515 \\
\hline PU3 & $\mathbf{0 . 7 0 7}$ & 0.427 & 0.425 & 0.369 \\
\hline PE1 & 0.639 & $\mathbf{0 . 8 0 6}$ & 0.614 & 0.589 \\
\hline PE2 & 0.517 & $\mathbf{0 . 8 0 6}$ & 0.593 & 0.684 \\
\hline PE3 & 0.521 & $\mathbf{0 . 8 3 0}$ & 0.584 & 0.688 \\
\hline DA1 & 0.649 & 0.622 & $\mathbf{0 . 8 7 7}$ & 0.784 \\
\hline DA2 & 0.619 & 0.634 & $\mathbf{0 . 8 7 1}$ & 0.602 \\
\hline ESAT1 & 0.567 & 0.730 & 0.661 & $\mathbf{0 . 8 6 2}$ \\
\hline ESAT2 & 0.545 & 0.755 & 0.670 & $\mathbf{0 . 9 0 6}$ \\
\hline
\end{tabular}

Sumber : Data primer $(\mathrm{n}=270$ responden $)$

Nilai diskriminan validitas pada semua variabel dikatakan valid dimana nilai cross loading masingmasing indikator lebih besar dibandingkan variabel laten lainnya. Berdasarkan hasil tabel diatas indikator setiap variabel telah memenuhi syarat validitas konstruk.

\section{Uji Reliabilitas}

Pengukuran untuk menguji reliabilitas dengan menggunakan PLS-SEM dengan program SmartPLS dapat dilakukan dengan dua cara yaitu dengan Cronbach's Alpha dan Composite Reliability. 
Jurnal Value, 16 (2), Hal. 441 - 452

Tabel 5. Composite Reliability

\begin{tabular}{ll}
\hline Variabel & $\begin{array}{l}\text { Composite } \\
\text { Reliability }\end{array}$ \\
\hline Perceived Usefulness & 0.838 \\
\hline Perceived Ease of Use & 0.910 \\
\hline Dinning Attitude & 0.909 \\
\hline E-Satisfaction & 0.944 \\
\hline
\end{tabular}

Sumber : Data primer ( $\mathrm{n}=270$ responden)

Tabel 6. Cronbach's ALPHA

\begin{tabular}{ll}
\hline Variabel & Crombach's alpha \\
\hline Perceived Usefulness & 0.712 \\
\hline Perceived Ease of Use & 0.868 \\
\hline Dinning Attitude & 0.851 \\
\hline E-Satisfaction & 0.921 \\
\hline
\end{tabular}

Sumber : Data primer $(\mathrm{n}=270$ responden $)$

Nilai Composite Reliability menunjukkan bahwa semua variabel diatas 0,7. Selain nilai Composite Reliability, nilai Cronbach's Alpha juga menunjukkan nilai diatas 0,7. Maka disimpulkan bahwa setiap variabel dalam penelitian ini dinyatakan reliabel karena nilai Composite Reliability dan Cronbach's Alpha masing-masing berada diatas 0,7 yang artinya telah memenuhi syarat yang telah ditetapkan.

\section{Uji Koefisien Determinasi (R-Square)}

\begin{tabular}{ll}
\multicolumn{2}{c}{ Tabel 7. Uji $\mathbf{~ r}^{\mathbf{2}}$} \\
\hline Variabel & $R$ Square \\
\hline Dinning Attitude & 0.697 \\
\hline E-Satisfaction & 0.707 \\
\hline Sumber : Data primer $(\mathrm{n}=270$ responden $)$
\end{tabular}

Nilai R-Square $\left(\mathrm{R}^{2}\right)$ menunjukkan bahwa variabel E-satisfation dipengaruhi oleh variabel Perceived Usefulness, Perceived Ease of Use, dan Dinning Attitude sebesar 0,707 atau 70,7\% dan sisanya dijelaskan atau dapat dipengaruhi variabel lain yang tidak teliti. Variabel Dinning Attitude dipengaruhi oleh Perceived Usefulness dan Perceived Ease of Use sebesar 0,697 atau 69,7\% dan sisanya dijelaskan atau dapat dipengaruhi oleh variabel lain yang tidak teliti.

\section{Uji t-statistik}

Hasil uji t-statistik ditentukan sebagai berikut:

Tabel 8. Hasil uji t-statistik

\begin{tabular}{|c|c|}
\hline Variabel & T Statistics $(|\mathrm{O} / \mathrm{STDEV}|)$ \\
\hline Perceived Usefulness -> Dinning Attitude & 3.648 \\
\hline Perceived Ease of Use -> Dinning Attitude & 2.234 \\
\hline Perceived Usefulness -> E-Satisfaction & 8.821 \\
\hline Perceived Ease of Use -> E-Satisfaction & 5.601 \\
\hline Dinning Attitude -> E-Satisfaction & 3.342 \\
\hline
\end{tabular}

Fakultas Ekonomi, Universitas Muhammadiyah Cirebon 
Hubungan variabel dikatakan signifikan apabila t-statistik lebih besar dari t-tabel yaitu 1,96. Berdasarkan hasil uji t-statistik diatas, dapat disimpulkan bahwa :

a) Perceived Usefulness berpengaruh signifikan terhadap Dinning Attitude, dimana Ho ditolak dan Ha diterima dengan nilai t-statistik 3.648>1,96. Penggunaan aplikasi online food delivery dianggap dapat memudahkan konsumen untuk mendapatkan makanan yang diinginkan tanpa harus mendatangi restoran. Hal ini semakin berpengaruh pada perubahan sikap konsumen dalam mengonsumsi makanan yang diinginkan. Adanya pembatasan sosial yang diterapkan oleh Pemerintah telah mengubah kebiasaan konsumen yang biasanya mengunjungi restoran untuk mengonsumsi makanan yang diinginkan menjadi menggunakan aplikasi online food delivery dan mengonsumsi makanan yang diinginkan di rumah (Al Amin et al., 2020)

b) Perceived Ease of Use berpengaruh signifikan terhadap Dinning Attitude, dimana Ho ditolak dan Ha diterima dengan nilai t-stattistik 2.234>1,96. Perceived ease of use merupakan faktor utama penentu penerimaan penggunaan suatu sistem teknologi. Ketika konsumen merasa suatu teknologi mudah untuk digunakan maka akan meningkatkan penerimaan konsumen atas teknologi tersebut. Kebijakan Pemerintah yang membatasi waktu makan di restoran dan bahkan ada beberapa daerah yang hanya memperbolehkan jasa antar bagi restoran, maka konsumen mulai memilih teknologi atau cara yang mudah digunakan dan dapat membantu mereka memperoleh makanan yang diinginkan. Ketika konsumen merasa teknologi atau suatu cara mudah digunakan, mereka cenderung akan menyukai teknologi atau cara konsumsi baru tersebut (Kang \& Namkung, 2019).

c) Perceived Usefulness berpengaruh signifikan terhadap E-satisfaction, dimana Ho ditolak dan Ha diterima dengan nilai t-statistik 8.821>1,96. Faktor pendorong utama agar konsumen menggunakan digital platform adalah kepuasan. Kepuasan konsumen untuk menggunakan aplikasi untuk melakukan transaksi pembelian dipengaruhi oleh manfaat yang dirasakan oleh konsumen ketika menggunakan aplikasi tersebut. Ketika konsumen merasa aplikasi online food delivery telah memiliki kinerja yang bermanfaat untuk memudahkan mereka dalam memperoleh makanan di saat adanya pembatasan sosial, maka mereka akan merasa puas terhadap aplikasi online food delivery tersebut (Al Amin et al., 2020)

d) Perceived Ease of Use berpengaruh signifikan terhadap E-satisfaction, dimana Ho ditolak dan Ha diterima dengan nilai t-statistik 5.601>1,96. Ketika konsumen menganggap aplikasi online food delivery mudah untuk digunakan, maka konsumen akan puas dan terus menggunakan aplikasi tersebut (Makanyeza, 2017). Masa pandemi Covid-19 dimana terdapat pembatasan jarak dan berbagai pembatasan sosial melalui PPKM level satu sampai empat membuat konsumen bergantung pada aplikasi untuk pemenuhan kebutuhan hidup, termasuk memperoleh makanan. Kemudahan penggunaan tersebut berpengaruh pada kepuasan konsumen dan membuat konsumen tetap menggunakan aplikasi online food delivery untuk memenuhi kebutuhan hidupnya.

e) Dinning Attitude berpengaruh signifikan terhadap E-satisfaction, dimana Ho ditolak dan Ha diterima dengan nilai t-stattistik 3.342>1,96. Sikap pelanggan merupakan salah satu elemen untuk mengukur kepuasan. Dinning attitude digunakan untuk mengukur sikap konsumen dalam mengonsumsi makanan melalui adopsi teknologi online food delivery. Ketika sikap pelanggan dalam mengonsumsi makanan melalui aplikasi online food delivery adalah positif, konsumen menjadi puas menggunakan aplikasi tersebut. Ketika sikap pelanggan dalam mengonsumsi makanan melalui aplikasi online food delivery adalah negatif, maka konsumen menjadi tidak puas terhadap aplikasi online food delivery (Al Amin et al., 2020).

\section{KESIMPULAN}

Kegiatan PSBB yang dimunculkan kembali dalam istilah PPKM (Pemberlakukan Pembatasan Kegiatan Masyarakat) semakin menegaskan kembali tentang pembatasan-pembatasan aktivitas sosial di masyarakat. Hal ini disebabkan karena virus Covid-19 tergolong mudah menular, khususnya melalui interaksi yang dekat antar orang ke orang. Pada masa pembatasan, masyarakat dihimbau untuk tidak berpergian, kecuali jika sangat diperlukan. Hal ini berdampak pada seluruh kegiatan ekonomi termasuk sektor bisnis restoran. Pandemi Covid-19 telah mengubah kebiasaan masyarakat yang lebih banyak 
memanfaatkan waktu luang untuk tidak pergi ke tempat ramai seperti restoran. Kapasitas restoran juga tidak diperbolehkan penuh juga telah menurunkan omzet pengusaha restoran. Tetapi hal baiknya adalah adanya terjadinya peningkatan transaksi di layanan pesan antar. Di tengah pandemi Covid-19 seperti sekarang ini, penggunaan online food delivery sangat disukai oleh masyarakat Indonesia. Keinginan masyarakat untuk terus melakukan pemesanan makanan secara online dipengaruhi oleh perubahan sikap masyarakat dalam menikmati makanan yang diinginkan. Konsumen yang mulai membiasakan diri menerapkan jarak aman untuk menghindari penularan Covid-19, merasa nyaman untuk menikmati makanan restoran yang mereka inginkan melalui aplikasi online dibandingkan harus mengunjungi restoran tersebut. Ketika konsumen merasa puas pada penggunaan online food delivery, maka konsumen akan berulang kali memesan melalui aplikasi tersebut.

\section{SARAN}

\section{Saran Teoritis:}

1. Penelitian ini bersifat cross-sectional dan dilakukan selama periode pandemi Covid-19 di Indonesia. Peneliti selanjutnya diharapkan dilakukan di masa yang berbeda (setelah pandemi berakhir) untuk mengetahui perbedaan perilaku konsumen atas penggunaan online delivery order.

2. Peneliti selanjutnya perlu meneliti tentang dinning attitude pada perilaku konsumen setelah pandemi Covid-19. Hal ini untuk mengetahui apakah dinning attutide yang berubah tersebut terjadi karena adanya pembatasan sosial ataukah bersifat permanen karena proses digitalisasi secara menyeluruh di seluruh aspek kehidupan.

\section{Saran Praktis}

1. Pergeseran dari offline menuju ke digitalisasi harus diawali dengan kemanfaatan dan kemudahan aplikasi. Pengusaha diharapkan menciptakan aplikasi yang dapat menciptakan kinerja lebih baik dan mudah untuk mendukung perubahan perilaku konsumen akibat adanya proses digitalisasi maupun kondisi pasca pandemi Covid-19.

\section{REFERENSI}

Al Amin, M., Arefin, M. S., Sultana, N., Islam, M. R., Jahan, I., \& Akhtar, A. (2020). Evaluating the customers' dining attitudes, e-satisfaction and continuance intention toward mobile food ordering apps (MFOAs): evidence from Bangladesh. European Journal of Management and Business Economics, 30(2), 211-229. https://doi.org/10.1108/EJMBE-04-2020-0066

Alex, D., \& Thomas, S. (2011). Impact of Product Quality, Service Quality and Contextual Experience on Customer Perceived Value and Future Buying Intentions. European Journal of Business and Management.

Baabdullah, A. M., Alalwan, A. A., Rana, N. P., Patil, P., \& Dwivedi, Y. K. (2019). An integrated model for m-banking adoption in Saudi Arabia. International Journal of Bank Marketing, 37(2), 452-478. https://doi.org/10.1108/IJBM-07-2018-0183

Bashir, I., \& Madhavaiah, C. (2015). Consumer attitude and behavioural intention towards Internet banking adoption in India. Journal of Indian Business Research. https://doi.org/10.1108/JIBR-02-2014-0013

Chiu, W., \& Cho, H. (2019). E-commerce brand: The effect of perceived brand leadership on consumers' satisfaction and repurchase intention on e-commerce websites. Asia Pacific Journal of Marketing and Logistics. https://doi.org/10.1108/APJML-10-2018-0403

Ghozali, I. \& L. H. (2015). Konsep, Teknik Dan Aplikasi Menggunakan Program Smart PLS 3.0. In Universitas Diponegoro. Semarang. https://doi.org/10.1002/14651858.CD002812

Guriting, P., \& Oly Ndubisi, N. (2006). Borneo online banking: Evaluating customer perceptions and behavioural intention. Management Research News. https://doi.org/10.1108/01409170610645402

Ha, H. Y., \& Janda, S. (2012). Predicting consumer intentions to purchase energy-efficient products. Journal of Consumer Marketing. https://doi.org/10.1108/07363761211274974

Hair, J. F., Hult, G. T. M., Ringle, C., \& Sarstedt, M. (2017). A Primer on Partial Least Squares Structural Equation Modeling (PLS-SEM) 2nd Edition. Sage Publications 
Jayani, D. H. (2021). Potensi Bisnis Pesan-Antar Makanan Daring Makin Besar. https://katadata.co.id/muhammadridhoi/analisisdata/60093900cb02f/potensi-bisnis-pesan-antarmakanan-daring-makin-besar

Kang, J. W., \& Namkung, Y. (2019). The role of personalization on continuance intention in food service mobile apps: A privacy calculus perspective. International Journal of Contemporary Hospitality Management, 31(2), 734-752. https://doi.org/10.1108/IJCHM-12-2017-0783

Kaur, P., Dhir, A., Talwar, S., \& Ghuman, K. (2020). The value proposition of food delivery apps from the perspective of theory of consumption value. International Journal of Contemporary Hospitality Management, 33(4), 1129-1159. https://doi.org/10.1108/IJCHM-05-2020-0477

Kotler, P., Kartajaya, H., \& Hooi, D. H. (2019). MARKETING 4.0: MOVING FROM TRADITIONAL TO DIGITAL. In Asian Competitors. https://doi.org/10.1142/9789813275478_0004

Makanyeza, C. (2017). Determinants of consumers' intention to adopt mobile banking services in Zimbabwe. International Journal of Bank Marketing. https://doi.org/10.1108/IJBM-07-2016-0099

Mustafa, Zainal EQ, dan Wiajaya, Tony, 2012. Panduan Teknik Statistik SEM \& PLS dengan SPSS AMOS, Yogyakarta, Cahaya Atma Pustaka.

Ngoc, K. M., \& Uyen, T. T. (2015). Factors Affecting Guest Perceived Service Quality, Product Quality, and Satisfaction-A Study of Luxury Restaurants in Ho Chi Minh City, Vietnam. Journal of Advanced Management Science. https://doi.org/10.12720/joams.3.4.284-291

Novita, N., \& Rowena, J. (2019). Determinant factors of Indonesian people's fish purchase intention. British Food Journal. https://doi.org/10.1108/BFJ-01-2019-0067

Permatasari, D. (2021). Kebijakan Covid-19 dari PSBB Hingga PPKM Empat Level. https://kompaspedia.kompas.id/baca/infografik/kronologi/kebijakan-covid-19-dari-psbb-hinggappkm-empat-level

Ryu, K., Lee, H. R., \& Kim, W. G. (2012). The influence of the quality of the physical environment, food, and service on restaurant image, customer perceived value, customer satisfaction, and behavioral intentions. International Journal of Contemporary Hospitality Management. https://doi.org/10.1108/09596111211206141

Saad, A. T. (2021). Factors affecting online food delivery service in Bangladesh: an empirical study. British Food Journal, 123(2), 535-550. https://doi.org/10.1108/BFJ-05-2020-0449

Siregar, S. (2017). Statistika Parametik untuk Penelitian Kuantitatif Dilengkapi dengan Perhitungan Manual dan Aplikasi SPSS Versi 17. In Statistika Parametik untuk Penelitian Kuantitatif Dilengkapi dengan Perhitungan Manual dan Aplikasi SPSS Versi 17.

Stocchi, L., Michaelidou, N., \& Micevski, M. (2019). Drivers and outcomes of branded mobile app usage intention. https://doi.org/10.1108/JPBM-02-2017-1436

Sugiyono. (2017). Metode Penelitian Kuantitatif, Kualitatif dan R\&D. Bandung: PT Alfabet.

Teo, T., \& Teo, T. (2011). Modeling the determinants of pre-service teachers 'perceived usefulness of elearning. https://doi.org/10.1108/10650741111117824

Wang, Y. S., Wang, Y. M., Lin, H. H., \& Tang, T. I. (2003). Determinants of user acceptance of Internet banking: An empirical study. International Journal of Service Industry Management. https://doi.org/10.1108/09564230310500192 